\title{
WEAPONS OF THE WEAK TWISTED IN JARS OF LOVE. THE TRANSNATIONAL MATERNAL FOODWAYS OF POLISH MIGRANTS IN BRUSSELS
}

\author{
SYLWIA URBAŃSKA \\ FACULTY OF SOCIOLOGY, UNIVERSITY OF WARSAW
}

\begin{abstract}
The aim of the article is to analyse social change in the area of the gendered care practices and identities of migrant mothers, who were forced by the social and economic situation in Poland to (illegally) work abroad without their children and families. It asks what kind of experiences of social change we can find if we look at the foodways practised by transnational mothers from the working classes. The concepts of "transnational maternal foodways" and "maternal bustling around foodways" will be used as tropes to discuss and explore the gendered changes in motherhood experienced by Polish migrants. The analysis presented here is based on the results of extensive fieldwork conducted both in the villages and small towns of Eastern Poland and in Belgium (particularly in its capital, Brussels), and on 54 autobiographical narrative interviews with Polish women who, during the two decades after the fall of socialism in Poland (1989-20I0), worked permanently or cyclically abroad. The analysis combines critical food studies with gender and migration studies.
\end{abstract}

KEYWORDS: transnational motherhood, foodways, gender, working class migrants, agency, (un) becoming mothers, Poland

The issue that especially caught my attention during ethnographic fieldwork in Brussels, conducted between 2007 and 2009 in the community of Polish transnational working class mothers, was a constant "bustling around" foodways (krzqtanie się, see

I The article analyzes data from the research project from the National Science Center "(Non)traditional traditionals? The transformation of rural famililies from the perspective of women in the years 1989-2019" (nr 2016/23/D/HS6/00705), part of which have not have not been analysed so far. The translation was financed by the Institute of Sociology, University of Warsaw (BST 173200). I would like to extend special thanks to Renata E. Hryciuk for her support in the process of preparing the article, and for creating a space for discussion at the anthropology of food seminars at the Institute of Ethnology and Cultural Anthropology, University of Warsaw. I would also like to thank Dr. Helena Patzer and my colleagues from the Institute of Sociology, University of Warsaw, for inspiring discussions and comments on subsequent versions of the text. 
Brach-Czaina 1999; Budrowska 2009). ${ }^{2}$ This term depicts an intrinsic part of the experience of women who, after the collapse of socialism, between 1989 and 2010 were forced to migrate alone and take up illegal work as agricultural, care and cleaning workers. This "bustling around" was integrated into the space of the city and into the transnational network of Polish migrants. It would fill every free moment and was also strictly regulated by an - initially unclear to me - complicated code. It was focused on dozens of activities that together formed what I call "transnational maternal foodways".

The proposed term seeks to encompass two distinct areas. The first of these is the relationship between mothers and children left behind in the care of others in Poland. This relationship was organised around common beliefs, behaviours and practices regulating long-distance maternal care through food and feeding work shared by both migrant and sending communities. The second is comprised of a series of embodied and affective norms and moral patterns related to everyday foodways, in other words by the behaviour of migrant women in Belgium entwined in a nexus of gendered food cultures (Counihan 1999). This includes all the interactions and processes involved in making food undertaken by migrant workers, such as planning, shopping, preparing, cooking, sharing and eating food. All these practices were carried out both inside and outside their rented flats, as well as in the various socio-territorial spaces of the working class in Brussels. What is more, this study deals with the migrant mother's attitude towards herself, to the needs of her body: its nutrition, taste, pleasure, discipline and (self-) control. This dimension is too often absent from analyses of migrant women's motherhood, which focus mainly on work and the caring dimension of the relationship between women and their families.

All the above-mentioned practices making up "transnational maternal foodways" and the "maternal bustling around foodways" were usually co-practiced, observed, commented on, narrated, confirmed and controlled, as well as "displayed" (see: Finch 2007) in female migrant groups. Most often, these were constituted by roommates from rented flats: friends, neighbours and relatives from the same villages and small towns in Poland. Thus, they never escaped the attention of the transnational community of labour migrants, stretched between Poland and Belgium.

The aim of the article is to analyse the change in the area of gendered care practices and the identities of transnational migrant mothers. More precisely, I want to ask what kind of experiences of social change we can find, if we look at the foodway models that are practised by transnational mothers from working classes. ${ }^{3}$ Through

2 The translation of the Polish phrase krzatanie sie is cited after the work of Kowalczyk $(2016,47)$. In Polish this term is particularly associated with movements around the kitchen and the household.

The export of Polish women to do care work abroad after 1989, and then after Poland's accession to the EU in 2004, concerned not only women from the working classes, but also from the middle 
this text I want to raise two theoretical questions. The first revolves around the question of agency and bargaining with patriarchy. The second pertains to the widening of the methodological discussion of female emancipation in migration, in order to include a more phenomenological approach, acknowledging women's feelings and emotions, body politics, intimacy and sexuality. To answer these questions, I will analyse data gathered during seven months of participant observation (carried out between 2007 and 2009). The group studied are mothers forced by the social and economic situation in Poland to work (illegally) abroad in the period of postsocialist transformation (1989-2010), and thus to leave their children and families temporarily in Poland. The ethnographic material consists of field diaries and 54 autobiographical interviews I conducted with transnational mothers in Belgium (Brussels and its surroundings) and in villages and small towns in Eastern Poland (Podlasie region). I analysed the narrations, but also observed non-verbalised, embodied practices of long-distance/ transnational maternal foodways, including food and feeding work. I focus both on the content of autobiographical experiences and analyse the interactions in which I participated with the female migrants. The analysis is situated in the context of migrant communities, and also incorporates the local communities exporting women's work.

The results of the study in the Polish context will make it possible to broaden the already considerable body of knowledge about the foodways' of overseas care migrants and transnational mothers from Asia (see Patzer 20I8; Camposano 20I8; Mata-Codesal and Abranches 2018) and Central and South America (Dreby 2006; Carling and Menjivar and Schmalzbauer 20I2). It will extend such approaches to the food experiences of migrants from Central and Eastern Europe, which are still understudied (see Main 20I6; Ślusarczyk and Pustułka 2016; Bielenin-Lenczowska 20I8). Focusing on food reveals new possibilities of interpreting patterns and the specifics of gendered emancipation in migration processes. It focuses primarily on the problem of the empowerment of the excluded: of working class mothers who feed into the European proletariat of migrant workers. The intensive development of food studies over the last decade in Poland (see Hryciuk and Mroczkowska 20I2; Bielenin-Lenczowska and Hryciuk 2018) and in the world (see Carrington 2007; Jackson 2009; Counihan and Van Esterik 20I3; Parsons 20I5; Counihan 2018) opens up an analytical focus that can usefully be applied to the experiences of Polish migrants.

class. In Poland, the enormous costs of the transformation from socialism to a neoliberal economy fell mostly on women, regardless of their class background. In the period 2004-2007 alone, over a million Polish women left to work abroad. However, in the study the group that interests me most is working-class women who have struggled with multiple exclusions. The undocumented status of my respondents - even after Poland's accession to the EU - is related to the fact that many EU countries opened their labour markets to Poles later. This was the case with Belgium, which fully opened its labour market for Poles only in 2009. 


\section{TRANSNATIONAL MOTHERHOOD, AGENCY \\ AND THE FOODWAYS OF WORKING CLASS WOMEN}

"Transnational maternal foodways" and a "maternal bustling around foodways" cannot
simply be interpreted in terms of the reproduction of patriarchy, since they constitute
an important weapon of the weak (Scott 1985) or strategy of bargaining with patriarchy (Kibria 1995), as I was to find more than once during my ethnography with migrant women. Especially when I unwittingly violated these norms by inviting my interlocutors - who lived in crowded workers' flats, deprived of intimacy - to research interviews in Brussels cafés. When once again, in response to the suggestion of a place to meet, I encountered a similar pattern of moral outrage and a firm refusal, my initial confusion began to gradually give way to an understanding of the gendered rules followed by migrants in their everyday foodway practices.

The theoretical framework that I propose opens up wider possibilities of how to interpret gender negotiations when analysing the practices of individuals and groups, who suffer multiple social exclusions, or whose lives are played out in patriarchal "strongholds". Emphasizing the ambivalent complexity of agency through food renders it more difficult to automatically qualify the continuity of involvement of migrant mothers in transnational foodways as a mere top-down reproduction of existing gender norms in the household. That is why all the practices that I define as "transnational maternal foodways" and the ways in which they are implemented on a daily basis through a "maternal bustling around foodways", will serve to direct attention to the work of the excluded. I will show that these eating and feeding practices can be interpreted in terms of "weak resistance" (Pasieka 2015). This can be seen more clearly when we place the activities of migrant mothers in the context of two wider processes that are closely linked to their migrations and of global impact.

Firstly, "transnational maternal foodways" are a response to the neoliberal mechanisms of forced uprooting women from intimate family relationships. This process particularly affects poor women, who join the ranks of the migrant proletariat, and includes those fleeing systemically normalized violence and a lack of institutional safeguards (Urbańska 20I6). In this context of coercion, and not infrequently illegal work and also poverty - and thus overlapping exclusions - resorting to practices associated with the traditional legitimate role of the "feeding mother", but in a new form adapted to transnationality, emerges as a strategy for fighting to maintain continuity of relations despite physical distance. Secondly, "transnational maternal foodways" become a struggle for the social recognition of the migrant woman as a mother. They take shape in the situation of a ubiquitous "context of suspicion" in relation to emigrating women and of various practices of "depriving them of their roles".

An important element of this deprivation of roles was the moral panic around Euro-orphanage in Poland, which broke out after the mass migrations of women 
related to Poland's accession to the EU in 2004. Euro-orphans were defined as abandoned children, left behind by migrant mothers. The reaction to this spectre included the institutionalization of control and disciplining activities of migrant families, and investigating and monitoring children at schools. It also exacerbated various forms of social suspicion and a lack of legitimacy with regard to migrant women's work, while at the same time brushing over the economic coercion and violence that pushed the women to seek survival elsewhere (Urbańska 2015). The actions of migrant women generated in such a threatening context display symbolic aspects of identity related to care and sacrifice, as well as bustling around and resourcefulness. Such actions in conditions of coercion and social stigmatization become a causative, often reflective form of political counteraction: a specific management of the trajectory of "(un) becoming a mother in the transnational context" (Urbańska 20I6), which has features of individual and collective women's resistance strategies.

The concept of "displaying families" (Finch 2007) that inspired me to develop terms such as "transnational maternal foodways" and "maternal bustling around foodways" helps to see this resistance in numerous interactions and in the "banal" micro-practices of everyday life. It assists in highlighting the identity-relational dimensions of maternal foodways, which take place on both sides of the border: in family settings and the sending community, as well as in the migrant communities. Janet Finch defines "display" as "the process by which individuals, and groups of individuals, convey to each other and to relevant audiences that certain of their actions do constitute 'doing family things' and thereby confirm that these relationships are 'family' relationships" (2007: 67). The concept of "displaying families" adds a social environment that should properly read, accept, and confirm these practices as necessary for the effectiveness of the process of family reconstitution. In my case, this perspective emphasizes the dimension of power negotiations by mothers and shows resistance and agency with regard to the trajectory of "(un)becoming a mother in the transnational context". Describing the different dimensions of the repertoire of "transnational maternal foodways", taking into account the perspective of displaying, I will try to address three of their elements: $w h y$ is display important in transnational practices of mothering by foodwork and feedwork; how is displaying done; and to whom do "long-distance care relationships" need to be displayed? (see Finch 2007, 67, original emphasis).

\section{LINKING FOODWAYS WITH A LOST DIMENSION OF MOTHERHOOD}

The next point I want to raise in this article is the need of including both a wider perspective on motherhood and the concept of foodways in the research methodology (Parsons 2015), which enables covering a wider scale of phenomena than just food and feedwork (DeVault, 199I). I propose that those aspects of motherhood which are 
absent from existing studies of transnational motherhood should be recognised and incorporated. This is primarily a question of adding to the analysis the subjective dimension of the migrant mother's relationship with herself. Among other things, this includes: her reflexive attitude towards herself as a woman, her relationship with her body (nutritional concerns, pleasure vs discipline), her intimate needs (sexuality) or needs related to pleasure, fulfilment and satisfaction, as well as notions of limitation, discipline and control. Through this approach, it will be possible to reveal further dimensions of "long-distance care" (Patzer 20I5; 20I8), as well as further aspects of the gender revolution in migration (Parreñas 200I).

Feminist theories of motherhood have for several decades emphasized that the inclusion of this dimension in analyses allows for a better understanding of subjectivity and the expression of a female "voice", how economic and political coercion plays itself out on the female body, and a break between "I" and "we" (see Hays et al. I995; Hryciuk and Korolczuk 20I4; Kronenberg 20I6). Unfortunately, works devoted to transnational motherhood do not encompass this important dimension, focusing mainly on numerous transnational care practices, the circulation of care and forms of its reproduction, or on conditions of the gender contract reconfiguration (e.g. Parreñas 200I; Lutz 20IO; 20I5; Pustułka, Struzik, and Ślusarczyk 20I5; Pustułka and Trąbka 20I8). This lack is one of the reasons why I argue for compiling a more complete repertoire of ways of looking at the lives of working mothers. Linking renegotiated, often emancipating areas of their lives, as well as looking at the numerous ambivalences and contradictions that emerge when these areas are brought into mutual relation, may reveal interesting dimensions of social change. I refer here primarily to the juxtaposition of the most-analysed areas of work and transformations of care with the question of how workers relate to themselves as women and to their own bodies or intimate lives, issues only sporadically analysed in the area of migration studies.

\section{TRANSNATIONAL MATERNAL FOODWAYS}

The panoply of "transnational maternal foodways" performed by migrant mothers is impressive. Efforts are made to continue virtually each of the dozens of activities performed by women in family homes in Poland that make up the work around food (cf. Carrington 2007; DeVault 199I), in a form adapted to transnationality. The physical absence of the mother in the home, which requires a reorganisation of "the division of feeding work and foodwork in the household" (cf. DeVault 199I), rarely involves a full gender role reversal. Daily kitchen management is transferred to the virtual sphere (of phones, letters, text messages, etc.), where the mother becomes a transnational manager. In the new context, despite the distance of hundreds of kilometres, she still does both household work and physical work related to food. First of all, she 
tries to maintain the status of a "gatekeeper": so she tries to plan, monitor and settle issues of food organization. On the one hand, these concern minor everyday issues, such as supervising the structure of family mealtimes and various nutritional concerns about the diet. On the other, it also involves decisions of greater importance related to nominating other people, usually women, sometimes institutions (boarding schools), to take over the everyday care and nutritional obligations of the mother, as well as the organization of a network of suppliers, or participating in the exchange of diverse barter favours in the neighbouring community (see Patzer 2018; Krzyżowski 20I3).

Interestingly, in addition to the dimension of transnational management, mothers' practices also include a number of activities related to their own regular provisioning of the household (Carrington 2007), i.e. collecting purchases and preparing homemade food to be sent back to their families. This involves a range of activities that compose a cyclical developing of a stock of food in packages and those related to them: learning where to buy "appropriate" food, grocery and marché shopping, sharing favourite or new meals and products with children (see: "social remittances" Levitt and Lamba-Nieves 20II; Patzer 20I5; 20I8) and saving on one's own costs of living and eating abroad. Finally, and most importantly, it culminates in sending homemade food back home in packages (Carrington 2007).

There are so many efforts involved in the transnational foodwork and feedwork activities, that if one tried to identify those that cannot be reconstructed virtually, one would actually be left just with dishwashing and cleaning the table after meals. Although sometimes efforts are also made to virtually control even this area, as managing mothers sometimes outsource people from outside the immediate family (relatives, neighbours) to perform such activities. And on more than one occasion, I ended up travelling on a bus with new or second-hand dishwashers sent to families (as well as microwaves, grills, washing machines, sets of pots, etc.). Let us now have a closer look at these strategies.

DISPLAYING TRANSNATIONAL MATERNAL FOODWAYS: "BUSTLING AROUND" AS BARGAINING WITH THE TRAJECTORY OF (UN)BECOMING MOTHERS

At this point, I would like to return to the analysis of the mysterious refusals of my interviewees mentioned above, which appeared in response to my proposal to conduct interviews in Brussels cafés over cake and coffee. It was the similarity of the structure of the statements of the invited women, who did not know each other and could not hear each other, that enabled me to read them as rules and be sure they were expressions of normative behaviours. The excuses for refusing were offered in longer sequences 
(accounts, see Scott and Lyman 1968). It therefore appeared that the very proposition of meeting in a café over coffee and cake was perceived as a stigma - as if I had assumed that the interlocutor belonged to the category of immoral women. A typical reaction was that of Anna, a thirty year old married woman and mother of two children, an economic migrant from a small town in Podlasie, who circulated alternately with her neighbour in a three-month system of house cleaning work. Although at first Anna willingly agreed to tell me about her experiences of transnational motherhood, explaining that she needed to speak to a stranger about her emotions, she reacted with indignation to my proposal to talk in a quiet café in Brussels: "I do not roam" around cafés here. I came here to work, not for pleasure." Upon my explanation that she would not incur any costs, because I would cover the bill from my grant allowance, and assurances that the café is a regular pastry shop, not a suspicious bar with dancing and alcohol, Anna refused even more strongly: "What would my husband think if somebody told him I was sitting here in cafeterias. You have to be very careful here, there are acquaintances everywhere, and people gossip" ${ }^{4}$

Anna's moral reaction, like that of other interlocutors, unveiled a gendered map of city spaces and urban practices marked with "moral suspicion” (Urbańska 2015). Above all, however, it unveiled a gendered evaluation of leisure activities closely linked to legally binding rules of displaying the identity of a migrant mother through foodways. The normative model of a good, committed, transnational migrant mother only allowed my interlocutors to work for the benefit of children and families: it forbade pleasures, which were burdened with the risk of casting doubt on women's economic motivations. In this way during their free time, which most of my surveyed migrants had only on Sundays (as on Saturdays most of them would work), only a "bustling around" focused on investing in family and children was an acceptable activity. It was in this Sunday bustling that proportionally the largest number of practices of maternal foodways were concentrated. Firstly, it incorporated the biological regeneration activities of a migrant woman who had to demonstrate resourcefulness, self-control and the ability to save on the food she bought and prepared. This entailed, for example, taking public transport to often far away stores and markets, to get the cheapest products to prepare several dishes for the whole week. This would be food intended to be heated "on the run" between houses cleaned in different parts of Brussels. Secondly, this "bustling around" in parallel also included a constant looking for cheap goods and gathering ordinary, as well as prestigious, goods or food, every now and then sent to Poland in parcels for children and families. There was a close relationship between these two activities, as it was thanks to saving on their own pleasures and a constant restraint of eating cravings that mothers could invest in the "pleasure of

The interview was recorded in my ethnographic diary. 
food play" (Parsons 20I5) of their children and families. ${ }^{5}$ Thus, a displayed "bustling around" and dedication turned the ordinary, routine labour of foodwork into emotional labour (Hochschild 1983), or "love labour" (Lynch 2007). It demonstrated a continuity of caring commitment and mother's love. It allowed, however, an extension beyond the boundaries of a "gender domestic sphere foodways' order" into everyday "banal" transnational food work and feeding the family still coded as emotional feminized activity. It also reproduced a multidimensional hierarchy in which the mother serves the needs of the child. Thus, thanks to this strategy of bustling around foodways, women gained control and an opportunity to reverse the process of unbecoming a mother: a process in which physical absence (non-residency) combined with entering the hegemonic role of a breadwinner was treated as abandonment (Euro-orphanhood). The display of such an attitude of bustling around, and thus resourcefulness, economy and sacrifice, in addition to practical necessity, could justify their separation from their children and also testify to legitimate motivations to leave. We can therefore see that the work of a migrant woman can be seen as valid, as Frances Pine described in her aforementioned study of Polish mothers from the Podhale region of Poland (2000). However, my research reveals another condition of this empowerment, in that it is only realized when there is no room for mother's free time and pleasure during the separation. It is expected that she should give up on herself and make sacrifices to provide the "pleasure of food play" to her child.

That is why I had to wait almost two months to record the interview with the aforementioned Anna. We did not meet until Anna’s roommate left for Poland for a while, thus giving us space for a confidential, intimate conversation. We could not talk in a park, because in Brussels, just like in London, it rains all the time. In the meantime, however, I had numerous occasions to accompany Anna and her group of friends, as well as migrants from other groups, on their Sunday foodways' "bustling around" rituals, and accompanying interactions and conversations. The pattern of only Sunday afternoon "free time" spent this way by the migrants rarely changed. Weekly routine expeditions to the Polish Catholic Mission masses, and to special "ethnic" call centres for migrants (Internet Cafés) with telephone booths enabling cheaper calls to Poland, were intertwined with joint expeditions to often distant markets for food provisions, intended for weekly consumption and carefully prepared packages.

5 Parsons uses this term to make a distinction that women in the kitchen do labour and men food play. "Men cooking for pleasure reinforces 'natural' distinctions between everyday food work carried out by women and the more exciting or expert food play men enjoy in the domestic sphere" (20I5, 7I); "The persistent distinctions between food play and food work contributes to the naturalizing of women's work within the home. Hence, 'feeding the family' is conceptualized as hurried, low skilled, mundane and routinised (DeVault 1991) unlike the artistry of the epicurean, which is not 'work' at all" (Parsons 20I5, 22). 
The Abattoir food market (Marché de l'Abattoir) was the most popular place of weekly shopping for the Polish community, functioning in numerous stories due to the possibility of purchasing the cheapest goods there: meat, vegetables and fruit. The market is located in the Anderlecht district, associated with the poorer proletariat and inhabited mainly by Polish and Arabic migrants. Although it happened that women tired of doing all-week-long physical work did shopping at places located closer to their apartments, the trip to l'Abattoir saved most money, because it made it possible both to buy food at reduced prices and to "collect" food (forced freeganism). Thanks to the joint expeditions to the market, I had a chance to observe embodied practices, which some of the interviewees either did not reflect on in interviews or were simply ashamed to admit to. Many of the products the women obtained were strategically won a quarter of an hour before the market closed, when sellers sold cardboard boxes with leftover goods for a few euros. These usually contained damaged, unattractive in appearance and overripe tomatoes, peppers, aubergines, various types of cabbage and lettuce, and bananas, as well as the fruit and vegetables which remained unsold. Women often strategically planned to arrive at the market an hour before closing: this was the time when prices for goods would fall sharply and it was possible to bargain for the last boxes. It was also a popular practice to collect fruit and vegetables left and scattered, after sellers left the market. The use of such strategies of resourcefulness was also suggested to me when an interlocutor during my research in Podlasie warned me, as a $\mathrm{PhD}$ student, about the high cost of living in Belgium. Some of my interviewees directly admitted, with a mixture of pride and embarrassment, that thanks to these time-consuming and somewhat shameful, but "justified" strategies, they were not only able to survive the economically difficult periods in exile, but above all, they could save more so that they could send more home.

The repertoire of this type of sacrifice, which made it possible to save on food and the high costs of living in Brussels, was indeed much broader. It was common practice to buy the cheapest products in the cheapest supermarkets and social shops ("look for products marked with one"), or to eat meals, whenever possible with patrons ${ }^{6}$, as well as to take individual products from their pantry (for example, onions, or two carrots for a soup)..$^{7}$ There were also situations, although probably less common, when migrant women admitted that they or their friends used an eatery for the homeless.

6 Economic female migrants in Belgium referred to their female employers as "patronesses", from the French patron.

7 The interviewees did not use the term "theft": rather they referred to the categories of resourcefulness, ingeniousness or cunning - categories positively associated with socialist resourcefulness in the case of an economy of shortages. Migrant women more often spoke about this type of practice in a generalised manner; however, several of my key female informants explicitly admitted to this type of practice. 
They also often explained that this happened in the first stage of migration, when salaries were lowest and other cheaper life strategies not yet discovered. Many migrant women also brought as much relatively cheaper food as possible from Poland, most often in the form of dry, long-term provisions: groats, pasta, canned meat and fish, homemade smoked and cured meats, homemade marinades and ready meals, usually meat, in jars. It is important to note that this food was often prepared during "holidays" in Poland (on several occasions, I transported such packages from my interlocutors' children/husbands). During this time, migrant women would make double supplies of homemade food: both for themselves for their time abroad and supplies of "motherly food" for children, suitably portioned, frozen and bottled. In the case of women from the countryside, these undertakings were often connected with ordering half carcasses of a piglet. This multi-sided bustling around crossed borders, and time-consuming foodways' display could also be used during stays in Poland to legitimize the image of separation in terms of sacrifice and time beyond the principle of pleasure.

In addition to the fact that for many workers these foodways' practices were motivated primarily by economic necessity, and thus were a survival strategy, the reflection and displaying of this embodied sacrifice and "bustling around" was also a coping strategy, which could easily be qualified as a strategy of resistance. This mainly concerned those groups of migrants who did not circulate in the several-month system (in a popular rhythm of three months in Belgium, three months in Poland), because they worked permanently abroad. Usually, these were distant mothers for whom migration following the opening of borders after 1989 opened the only available path for marital separation, and the possibility of divorce or preparation for it. For many of these women from the working class, the migration option was the only available form of escape from domestic violence, sometimes one advised by helpless representatives of institutions (police). It was also a way of dealing with the conservative tendency, rooted in Polish Catholicism, to normalize and invalidate domestic violence, and a related pressure to stay in marriage despite problems (Urbańska 20I5).

The mothers in this group were the most threatened by the process of (un)becoming mothers, as they dared to change and confront the normative expectations of self-sacrificing, of the need to be an altruistic, asexual wife and mother (a "Polish Mother", see Hryciuk, Korolczuk 20I2). In addition, by emancipating themselves abroad, they sooner or later tried to use their newly acquired and hard-earned economic independence and the liberal moral context to shape their lives anew, on their own terms. Women in this group might therefore look for romantic relationships, pleasure, sexual fulfilment and also another marriage, al though equally some, discouraged by the latter formula, decided on civil partnerships/unions inaccessible and invalid in conservative Poland (Urbańska 20I5). These women were the most affected by the context of suspicion, of a failure to recognize and questioning of the status of mother, as well as by 
the stigmatization strategies widespread in the migration environment. Their presence introduced a moral anxiety about the impact of the pattern of their migration (and emancipation) on the morality of Polish women (especially wives and mothers). It increased mutual control and distrust, generated gossip and moral judgements and divided the migration environment.

Recognizing this group of subversive mothers and the tension-ridden diversity of the migrant women of working classes in general allowed me to understand why Anna and other economic migrants refused being invited for coffee and cake so strongly. And, consequently, why they felt compelled to explain to me their identity, in which the major point of reference was sacrifice through the (display of) foodways and the principle of being cut off from the sphere of pleasure. Paradoxically, however, the pattern of displaying maternal bustling around foodways was even more strongly represented in "subversive" mothers, with whom, for a change, I was free to talk in cafés (they accepted invitations also to bars; some invited me to a dance) and in their homes (they usually rented small studios themselves). For example, Barbara, Wanda and Aldona were such mothers for whom, at first, forced economic migration coincided with the experience of separation, divorce and fighting for children and their upkeep. At the same time, it also entailed a process of arranging romantic life, on different principles and from scratch. For Barbara, Wanda and Aldona, each of whom in exile sooner or later was in a (not always constant) relationship with someone, showing sacrifice and "bustling around" foodways was the most effective "weapon of the weak" or strategy of bargaining with patriarchy.

The women in this group performed practically the same practices as economic migrants, with the difference that they performed them more intensively. They also paid more attention to the interactive communication of embodied sacrifices: especially when they negotiated/bargained their image of a mother tight-roping between hard work, physical absence in their children's homes, the commitment of a mother and finally the right to have their own romantic life. For example, Barbara used to send her daughter living in a dorm "homemade food prepared from scratch" (see: Parsons 2015 ) at regular intervals. This would be the daughter's favourite veal stew or stuffed cabbage, usually packed in jars, or portioned breaded cutlets. During the conversation we had at her house, Barbara showed me a blue, portable, plastic fridge with a handle, in which jars and frozen chops rode I2-16 hours by camionette from Brussels (stationed between Hôtel des Monnaies and Louise) to Poznań at a price of 20-30 euros. Moreover, she told me with undisguised satisfaction that her dishes were appreciated by her daughter's friends from the dormitory and that she, as a mother, provoked admiration with these practices. For Barbara, homemade food became a more effective form of showing affection and motherly love and care than the important, but not as strong symbol of motherly love, alienated money (see Patzer 20I8; Camposano 20I8). "Food not only nourishes but signifies" (Fischler 1988, 276), hence the packed jars 
and frozen foods are real "weapons of the weak". Barbara tries to send much more so that her daughter can offer (and display) this supranational "love of her mother" to her friends. Although not all my long-term interlocutors could afford such practices for financial and family reasons, Barbara could, because she had only one daughter in a big city well connected to Brussels. Despite such restrictions, virtually every mother reflected and displayed in her interactions with children, family and social circles embodied foodways' practices of bustling around and sacrifice.

Wanda, who as a cleaner tried to maintain two households, one for herself in Brussels and that of her four children in the care of her mother-in-law in Poland, was unable to send packages. Instead, she regularly sent all the money she put aside to support her family to her mother-in-law, who had moved to Wanda's apartment and retired early to look after her granddaughters. Wanda explained to her daughters that she was not able to earn enough working as a cleaner and babysitter to send extra items in packages. She explained that even buying a bar of chocolate for everyone in Poland was too much of a burden for her tight budget. And when her relatives in Poland did not trust her explanations, because they still encountered a strong post-socialist representation of migrants and their families as living in luxury, then Wanda tried to display to her family her living conditions and her complex food survival strategies in a context of illegality in Brussels. In order to gain the support of her teenage daughters, provoked into rebellion by their violent father, she confessed to them that she collected scattered vegetables from markets, used an eatery for the homeless and had tried unsuccessfully to ask for financial help and accommodation in Polish Catholic Missions. She also admitted that at a time when her only job was night care for a sick elderly lady (she was only employed at night), to save on the cost of renting an apartment, she remained homeless for several months. This was a period when she would leave her suitcase behind the counter with a befriended shop assistant, and spend days walking around the city looking for work and social meals. When, after many years, she allowed herself to have a romantic relationship with a migrant from Congo, the initial resistance of her daughters and the moral accusations of her mother's identity were negotiated with the argument that a hardworking worker, "scrubbing someone else's toilet on her knees every day, deserves pleasure". So Wanda not only rejected the "migration lie" strategy (Sayad 2004), she also bargained with Polish patriarchy, using the hegemonic pattern of a Polish Mother's dedication to lead to its subversion through her own path of individualisation and sexual emancipation.

Although at first glance these strategies could be interpreted in terms of (re)traditionalization, nothing could be further from the truth. Rather, we are dealing here with a process of becoming a postmodern mother in a working class migrant's version. A similar pattern of reflective, strategic transformation of symbolic capital flowing from guardianship and transnational bustling around into legitimizing family identities in the process of emancipation was also strongly rooted in the practices of the other migrants. 


\section{GATEKEEPING OR LACK OF ROLE REVERSAL? \\ TRANSNATIONAL MANAGERIALISM}

Another dimension of "transnational maternal foodways" practices was that of managing food and feedwork in a household stretched across borders. In the new circumstances, these practices took the form of transnational (virtual) management. The women tried to maintain their position of pre-departure food gatekeepers (Radcliffe and Weismantel 1990; Stoller 1989, I5-22; McIntosh and Zey 2003) and despite the distance they continued to monitor, organize, delegate and control various aspects of veryday family foodways. They had a major impact on the overall management of food provision and family meals (mealtimes) and, above all, on the organisation of their replacement in this area and attempts to control the quality of food provision. Moreover, thanks to the material capital acquired through work abroad, their position as foodway gatekeepers, and thus their position of power, would often strengthen. Such a situation did not result only from coercion connected with rarely successful role reversals with fathers. The desire to maintain influence and control over the process of unbecoming mother was also important.

First of all, women tried to virtually monitor and participate in everyday family meals. I learned about this not only during interviews and free time spent with migrants or their families in Poland. This was also confirmed by covert observations that I conducted in low-cost "parlours" (term used by respondents) for Polish migrants in the multi-ethnic, Saint-Gilles district popular among female workers. I regularly used several Internet café points besieged mainly by migrants from Podlasie. There, while writing up my diary, I could at the same time hear spontaneous conversations leaking out of the booths. Similar results were obtained each time for several hours of observations carried out on buses on the Siemiatycze-Brussels route and on the way back. Food was a constant topic of telephone conversations with children and families. Migrant women asked about daily menus, which they helped to plan, suggested recipes and taught children to cook. In the course of the talks, they expressed concern about the appropriate diet of individual family members, as well as all kinds of nutritional concerns. They also tried to monitor the rhythms of the day, e.g. correcting the right time for family meals in Poland. This was an important form of building everyday intimacy, as well as showing proper gender engagement from the limited set of possibilities available in virtual space.

The second type of transnational management practices was the organisation of food and feedwork substitution in Poland, including monitoring its quality. The patterns regulating who will replace the mother in the kitchen and when, reveal ethno-local gender norms, as well as the women's access to various types of local networks, local community institutions, and financial resources. Women rarely talk about full role reversal, where the responsibility for family foodways is taken over by the father. 
The prevailing pattern is one where the main responsibility for food and feedwork is transferred on the basis of nominations of other women (cf. Parreñas 200I; 2005; Carling, Cecilia Menjivar and Schmalzbauer 20I2, 5). These are primarily (I) older daughters or mothers-in-law, as well as relatives (sisters, aunts) associated with family responsibilities.

An important role, especially in rural communities, is also played by (2) women from the nearest neighbourhood or local community (friends, close neighbours). Here, however, the organisation of the replacement takes place not on the basis of nomination or use of related relationships: rather, it is largely grounded in a rural, self-help institution strongly rooted in women's practices (see Szpak 2013). An interesting example of using both strategies, despite the strong commitment of fathers, is the case of Danuta ( 2 children) and Jagoda ( 3 children). These two economic migrants are neighbours in a small town in the east of Poland and, at the same time, each other's substitutes. They exchange work with the same employers in the system of 3 months cleaning in Belgium and 3 months vacation in Poland. In each household, the responsibility for food and feedwork is taken over by fathers and daughters. Additionally, during the absence of each of the neighbours, her substitute helps her friend's full-time working husband by organizing care and meals during his absence (hours on duty at work, short trips). She invites children for dinners, offers them cake and drops off shopping and agricultural produce brought from gardens and from families from surrounding villages. At the same time, the women remain in constant telephone touch with each other, managing their households, and arranging purchases and deliveries at a distance (e.g. ordering eggs, half-carcases of piglets, etc). An additional support for both families is the retired older sister of Jagoda's mother. She often helps out in the care of the children of both neighbouring households in exchange for numerous gifts and financial help that she accepts with resistance because of family relations. The households of the two women are thus connected by a complex network of mutual relations crossing national borders: relations managed virtually by both women, and including networks of close and further women. Interestingly enough, this popular coping strategy is not based on the codified care chain (cf. Parreñas 200I; 2005; Hochschild 200I; Lutz 20I8) so common in other parts of the world. Rather, we are dealing here with the use of ethno-local patterns (see Radziwinowiczówna, Rosińska, Kloc-Nowak 2018), based on a complex network of bartering. They are governed by gendered expectations: the women know who should help in what situations and to whom this help should be offered. Commodification does not replace this pattern, but rather serves to complement it.

The other side of this circulating network of barter favours are conflicts, tensions and various types of hierarchies of inequalities that are formed in close relations. They are the result of a failure to renegotiate the gender contract with the partner and the overload of the gendered roles of women. An interesting example is the case of 
the former farmer Aldona, a forced economic emigrant and mother of 2 children, who emancipated in the process of migration from a violent relationship with her husband and in-laws. Aldona's husband did not take up any paid work, he neglected farming and childcare, engaging instead in the grass-root politics of the conservative Samoobrona party active at that time. ${ }^{8}$ Throughout the whole period, he exploited his wife financially, who became the only breadwinner of the family, forcing her to prolong her work abroad and to part with her children. What is more, during Aldona's stay abroad, he did not take care of the children, completely ceding care work to his mother, relatives and a neighbour, a friend of his wife. Until her divorce, which preceded the bringing of her younger daughter abroad, Aldona had been trying to manage her care at a distance through several years of separation. She regularly sent food packages, set up her contacts in the village and organised a network of fresh food purchases delivered straight to her home. Twice a week, a befriended bread courier brought home fresh buns, bread and dairy products for breakfast. Throughout her absence, food and feedwork - in exchange for friendship and gifts - was organized by Aldona's friend, who is also her neighbour. The friend cleaned the house, paid the bills, did shopping and regularly invited the children for home-cooked meals. Aldona's strategy was therefore based on transnational management of foodways and the use of gendered, local rules for supporting women and families, wherein a large role is played by the institution of rural neighbourhood self-help. In addition, Aldona practiced "maternal bustling around foodways", regularly sending parcels that change content during the course of her process of emancipation (unbecoming wife). At the instigation of Belgian employers whom she told about her marital problems, Aldona over time turned the initial financial transfers exclusively into gifts (food, household chemicals, clothes for children). This allowed Aldona to take control over her family's consumption and stop her husband from wasting her hard-earned money.

Aldona, like other migrants, also interweaves regular home visits in her management strategy. During her stays, she replenishes food in the pantry, cooks and freezes meals for the next few weeks, prepares and portions semi-finished products (chops) and makes preserves. Krystyna, an economic migrant and mother of 2 children, also mentions such a strategy of serving her family and husband in emergency situations, as did Aldona and other women. When one of Aldona, or Krystyna's children gets sick (a high fever), they negotiate a few days' holiday with their employer and go home for a dozen or so hours by camionette to watch over and cook their home broth (mother's homemade food as part of folk medicine, see Mroczkowska 20I4). Strategies of transnational management, and at the same time the status, position and identity of the mother, are reinforced here by regular visits and work in the territorial

8 The Self-Defense of the Republic of Poland is a Polish conservative-agrarian political party founded in I991. 
space of the home. Some of the women decide to move the location of their workplace to a place closer to their home towns. They move from Belgium to Germany: all this, in order to be able to commute home at weekends or twice a month. An additional interesting possibility is to intertwine local institutions with these strategies. For instance, older children (secondary school level) may be moved to Catholic boarding schools, which provide adequate care and boarding in canteens during school days, and thus relieve fathers and supporting women from excessive responsibilities, as especially arise in the case of families of mothers with many children.

\section{LOVE BOX: FOOD CHOICE AS A FOOD VOICE}

"For many women (and some men), food is a significant voice of self-expression. In the meals they cook, the rituals they observe, and the memories they preserve, women communicate powerful meanings and emotions" (Counihan 2012, I74). The packages around which migrants are constantly bustling, and the selection of their content, constitute an important practice of constructing and renegotiating the mother's new identity. The selection of a package, or food choice - in emigration conditions - is part of prestige related social messages (Camposano 2018; Levitt 1998; Patzer 20I8). By becoming a gift, it turns into a food voice (Counihan 20I2).

First of all, for a mother who needs to reconstruct her role in terms of distance and a context of suspicion, this gift involves the expression (voice) of emotional continuity and commitment. With the help of packages, mothers develop a kind of intimacy code. The package becomes a measure of the status of relationships, which is why all changes in their content and the routines of their dispatch are noticed and interpreted. What matters here is both their content, size and the frequency of deliveries, but also the context and time of sending them, because in the sending communities the parcels are expected to be inscribed in the life events of family members, such as birthdays, anniversaries and festive cycles. Second, through packages mothers often try to construct a new (class) social position and power. Food choice expresses the class aspirations of migrant women and is perceived in such categories in a supranational community. These two dimensions, maternal commitment and status, are in fact closely linked. Therefore, the package becomes a form of establishing a new status of mothers as "successful providers", i.e. a kind of transnational intensive mother in the working class (see: "intensive mothering", Hays 1996; and "transnational intensive motherhood", Parreñas 20oI). This specific "food voice" becomes an active transformation of access to economic capital into constructing the identity of a "good mother" in the family and in the community. Thus, it is a kind of simultaneous display of commitment, health care, parenting and pampering the child, as well as a display of class mobility. 
This is why packages contain not only "home cooked meals" or "mother-made food", but above all prestigious food. The latter was composed primarily of foodstuffs more difficult to access in the countryside or small towns in the first decades after 1989, namely exotic fruits such as oranges, coconuts, melons and kiwi, and spices and nuts. The most important of these, however, were sweets, and to be more precise, Belgian chocolates known all over the world: pralines (so-called "mussels"), chocolate bars, multi-packs of candy bars and brown sugar that was still unknown or not very popular in Poland at the time. These products are mentioned on both sides of the border, by mothers and by the adult children with whom I had the opportunity to talk. These items were also chosen for various types of barter favours. Moreover, it is striking that while it was these particular foodstuffs that were packed most often, many migrant women at the same time expressed a great distance to other Western foods. Belgian bread, meat or vegetables were usually described in opposition to "homely", Polish and rural food, as more expensive and worse, because they were less tasty. ${ }^{9}$ These products also construct new patterns of taste and demonstrate mothers as successful providers by providing food: (I) not available in children's homes; (2) unavailable to the average budget; (3) known for their nutritional values; or (4) unique taste qualities.

Food packages were also important signs saturated in a multitude of meanings in the family and sending community. I have participated in sending and receiving packages many times. I was asked to transport them, I delivered them and participated in their unpacking, criticism or affirmation. These were usually single, bigger bags. They were not large, as is the case of the balikbayan boxes widely known in migration literature travelling on a ship sailing for weeks from the USA to the Philippines (see Patzer 2018). On the other side of the border, in Poland, packages also had their place in the social imagination. My interlocutors (fathers and children) were waiting for packages: the whole family would go to the nearest town (to the international bus station) to pick them up. Receiving a package was an important social event, it initiated various types of social gatherings and associated exchange of gifts or barters (usually of sweets). Packages generated emotions and moral narratives: they were spoken about in the immediate vicinity and recognized as proof of sacrifice and dedication. The sender's nearest and dearest noticed resourcefulness, care and individualized memory: a remembering of the tastes, preferences and favourite flavours of family members. They assessed or criticized the mother's effort and choices, or the sense of her work abroad. The packages were also a third (non-human) actor in negotiating the mother's identity and the sense of her departure with her children and other adult family members. They were also an instrument of power. Having realized that her husband

9 To prove this thesis, migrants gave examples of the products for which Belgians shopped in Polish stores in Brussels: these included, among others, challah. 
did not care for her children properly and that he would spend the money she sent to him on his love affairs, Aldona stopped sending cash. Instead, she started sending different items in packages. Other women do the same. Paradoxically, therefore, departure does not always weaken the position of the mother: sometimes it even strengthens it because of the access to financial resources and the power to distribute them, that it affords (see: Patzer 20I8; Camposano 2018). In absentia, some of the women would gain more capital for gatekeeping.

\section{CONCLUSIONS}

I will now return to the key questions posed at the beginning of the article. Are we dealing with social change in the area of transnational mothers' gendered practices and identities? What do the food and foodway patterns of Polish transnational migrant mothers from working classes tell us about these experiences?

At first glance, the answer to this question seems unequivocal. It could be phrased as follows: as a result of migration, in the families of transnational mothers it is difficult to come across patterns of successful role reversal and transnational mothers continue to follow, or even enact with greater intensity, traditional patterns of food- and feedwork. They do this on their own and/or with the help of a network of close female relatives and friends. Such an interpretation would be difficult to refute in the light of the ethnographic and narrative data I collected. For these demonstrate a ubiquity of transnational care activities carried out by women: a constant bustling around, even at a great distance from the family home. They also bear witness to numerous moral restrictions (of control and suspicion) regarding free time and ubiquitous pressures on the display of maternal respect and self-sacrifice, also self-enforced by migrants themselves. An attractive thesis on retraditionalization would also fit well into a contemporary trend of international research, which focuses on showing bipolar directions of gender change in particular areas - unfortunately usually presented separately and fragmentarily - such as work, intimacy, religion and care (see Urbańska 20I8).

However, I do not intend to stop at this interpretation of retraditionalization. As I have shown in the analysis, looking at the experiences of migrant women becomes more complicated when, first of all, we recognise and incorporate their complexity into the study. It is, after all, difficult to analyse separately the changes taking place in particular areas of life: changes in care are closely related to changes in work, intimate life (relationships, sexuality), and attitudes towards oneself. Secondly, the experiences of migrant women will not appear so unilateral when we recognise and incorporate into our interpretations the intersectional location of their practices: a dimension which is so important in the study of gender patterns, care and family life. The women I focused on in my study not only joined the European ranks of a migrational 
illegal proletariat in Brussels. As working class members of the population, women from villages and small towns, second-class citizens deprived of protection against violence or mothers stigmatized by a discourse about Euro-orphanage, these women suffered multiple exclusions both in Poland and abroad. It was in relation to this specific social and economic context that they had to transform their family practices and identities. They also transformed them within a specific transnational migration community, combining new gender patterns in the Polish diaspora in Belgium with the communities that exported women's work. This network has developed many new gender patterns of moral control and suspicion in response to postmodern social change.

If we take into account these contexts, it is better to risk the claim that we are dealing here not so much with re-traditionalization, as with the development of a postmodern working class motherhood. First of all, mothers become breadwinners, trying to combine work with a new form of transnational (virtual) motherhood in their communities. What is more, some of them include in their migration trajectories the option unavailable in their communities of an emancipatory process of becoming an ex-wife and non-resident mother, and then entering into modern forms of second relationships. Second, in such an unfavourable context it is difficult to identify the entire "transnational maternal foodways" described here, or what I call "maternal bustling around foodways", simply with the notion of re-traditionalization. Rather, these practices are causative coping strategies, or strategies of workers' resistance to neoliberal uprooting mechanisms or violence. They are also a form of management of the trajectory of unbecoming a mother: a construction of relations and at the same time a struggle for social recognition in spite of the ubiquitous context of suspicion. From the perspectives of a transmigrant woman, it is not the issue of a choice of motherhood style, but a fight for the right to motherhood, to mothering that is in jeopardy in a transnational era. The women I focused on in my study strategically bargained with patriarchy in order to maintain continuity. The image of the Polish Mother (see Hryciuk and Korolczuk 20I2) returns here, but in a new strategic guise. In many cases, it now accompanies emancipatory processes not only in the area of work, but also in the area of relationships or sexuality. Ethnography, therefore, does not allow for simplification.

\section{REFERENCES}

Bielenin-Lenczowska, Karolina, Hryciuk, Renata. 20I8. "Anthropology of food and mobility - Introduction." Studia Socjologiczne 4 (23I), 75-76. http://doi.org/IO.24425/I22483.

Bielenin-Lenczowska, Karolina. 20I8. "Pierogi z fiżonem. Praktyki jedzeniowe i tożsamość Brazylijczyków polskiego pochodzenia w południowobrazylijskiej wsi." Studia Migracyjne - Przeglad Polonijny I (I67), 23-47. http://doi.org/I0.4467/25444972SMPP.18.002.8911.

Brach-Czaina, Jolanta. 1999. Szczeliny istnienia. Kraków: Wydawnictwo eFka. 
Budrowska, Bogusława. 2009. “Krzątactwo codzienności a perspektywa „trzeciej socjologii.” In Kobiety-Feminizm-Demokracja, edited by Bogusława Budrowska, 70-92, Warszawa: Instytut Filozofii i Socjologii Polskiej Akademii Nauk.

Camposano, C. Clement. 2018. "When objects speak louder than words: food, intimacy and power in the contemporary transnational Filipino household." In Food Parcels in International Migration. Anthropology, Change, and Development. edited by Mata-Codesal, Diana, and Maria Abranches. eds. Palgrave Macmillan: Cham. 73-93. http://doi.org/Io.I007/978-3-319-40373-I_4

Carling, Jørgen, and Cecilia, Menjívar, \& Schmalzbauer Leah. 20I2. "Central themes in the study of transnational parenthood." Journal of Ethnic and Migration Studies 38 (2), 19I-217. https://doi. org/10.1080/1369183X.2012.646417

Carrington, Christopher. 2007. "No place like home: The division of domestic labor in lesbigay families." In Shifting the center: Understanding contemporary families ( $3^{\text {rd }}$ edition). edited by Susan, J. Ferguson, 709-725, Boston: McGraw-Hill. https://search.ebscohost.com/login.aspx?direct=true\&db $=$ psyh\&AN=2006-22504-043\&site=ehost-live\&scope $=$ site\&custid=s5099II 8

Counihan, M. Carole. 2019. "'Mexicanas' food voice and differential consciousness in the San Luis Valley of Colorado* r." In Food and Culture. A Reader. edited by Carole, Counihan, and Penny, Van Esterik, Alice, Julier, I9I-204, New York: Routledge. http://doi.org/IO.4324/9781315680347-I4.

Counihan, M. Carole. 1999. "Food, culture and gender." In The Anthropology of Food and Body: Gender, Meaning, and Power. edited by Carole, M. Counihan, 6-24, New York: Routledge.

Counihan, M. Carole. 20I8. "Introduction." In The Anthropology of Food and Body: Gender, Meaning, and Power, edited by Carole, M. Counihan ed.. New York: Routledge. http://doi. org/IO.4324/9781315656540

Counihan, M. Carole, and Penny, Van Esterik. eds. 2013. Food and Culture. A Reader (Third Edition). New York: Routledge.

DeVault, Majrorie L. (199I). Feeding the Family: The Social Organization of Caring as Gendered Work. Chicago: University of Chicago Press. I38-163.

Dreby, Joanna. 2007. "Children and power in Mexican transnational families." Journal of Marriage and Family 69 (4), I050-1064.

Finch, Janet. 2007. "Displaying families introduction: Establishing the concept of display." Sociology 4I(I), 65-8I. http://doi.org/I0.1177/0038038507072284

Hays, Saron. 1996. The cultural contradictions of motherhood. New Haven and London: Yale University Press.

Hochschild, Russel Arlie. 1983. The Managed Heart: Commercialization of Human Feeling. Berkeley, CA: University of California Press.

Hryciuk, E. Renata, and Joanna, Mroczkowska. 2012. "Co wy tam gotujecie? O antropologicznych badaniach nad jedzeniem.” „op.cit. Maszyna Interpretacyjna”, 43, 3-6.

Hryciuk, E. Renata, and Elżbieta, Korolczuk. 20I2. "Wstęp: Pożegnanie z Matką Polką?”, In Pożegnanie z Matka Polka? Dyskursy, praktyki i reprezentacje macierzyństwa we wspótczesnej Polsce. edited by Hryciuk, E. Renata, and Elżbieta, Korolczuk. 8-20, Warsaw: University of Warsaw Press. http://doi.org/IO.31338/uw.9788323511175.

Hryciuk, E. Renata, and Elżbieta, Korolczuk. 20I4. “Macierzyństwo.” In Encyklopedia gender. Pteć w kulturze. Wydawnictwo Czarna Owca, 275-279.

Jackson, Peter. 2009. "Introduction: food as a lens on family life." In Changing Families, Changing Food. Palgrave Macmillan Studies in Family and Intimate Life. edited by Peter, Jackson, I-I6, London: Palgrave Macmillan. http://doi.org/Io.I057/9780230244795_I

Kibria, Nazli. 1995. Family Tightrope: The Changing Lives of Vietnamese Americans. Princeton University Press. 
Kowalczyk, Izabela. 20I6. "Aleka Polis: cleaning (for) democracy." Czas Kultury (3), 44-59.

Kronenberg, Anna. 2016. "Women's migrations: strategies of regaining one's voice and body in literary works by Polish women in the UK and Ireland.” Teksty Drugie (3), 98-II5. http://doi.org/I0.I8318/ td.2016.3.6.

Krzyżowski, Łukasz. 2013. Polscy migranci i ich starzejący się rodzice: transnarodowy system opieki międzygeneracyjnej. Warszawa: Wydawnictwo Naukowe Scholar.

Levitt, Peggy. 1998. "Social remittances: migration driven local-level forms of cultural diffusion." International Migration Review 32 (4), 926-948. http://doi.org/I0.2307/2547666.

Levitt, Peggy, and Lamba-Nieves, Deepak. 20II. "Social remittances revisited." Journal of Ethnic and Migration Studies 37 (I), I-22. http://doi.org/I0.1080/1369183X.2011.52136I.

Lutz, Helma. 2010. "Gender in the migratory process." Journal of Ethnic and Migration Studies 36(ro), I647-I663. http://doi.org/I0.1080/1369183X.2010.489373.

Lutz, Helma. 2015. "Myra's predicament: motherhood dilemmas for migrant care workers." Social Politics 22 (3), 34I-359. http://doi.org/Io.I093/sp/jxvo22.

Lynch, Kathleen. 2007. "Love labour as a distinct and non-commodifiable form of care labour." Sociological Review 55 (3), 550-570. http://doi.org/I0.IIII/j.I467-954X.2007.007I4.X.

Main, Izabella. 20I6. "Zmiany praktyk jedzeniowych wśród polskich emigrantek w Barcelonie i Berlinie." Studia Migracyjne - Przeglad Polonijny, 42 (2 (160)), I35-I56.

Mata-Codesal, Diana, and Abranches, Maria. 20I8. "Sending, bringing, consuming and researching food parcels." In Food Parcels in International Migration, edited by Diana Mata-Codesal and Maria Abranches, I-2I, Palgrave Macmillan. http://doi.org/Io.Io07/978-3-319-40373-I_I.

Morgan, H. J. David. 1996. Family Connections: an Introduction to Family Studies. Cambridge, UK; Cambridge, MA: Polity Press Blackwell Publishers.

Mroczkowska, Joanna. 20I4. "Gospodyni, matka, uzdrowicielka. Rola kuchni w kształtowaniu tożsamości współczesnych kobiet wiejskich." In Terytoria smaku. Studia z antropologii i socjologii jedzenia. edited by Agnieszka Wieczorkiewicz, and Urszula Jarecka, 73-88, Warszawa: Wydawnictwo IFiS PAN, Instytut Antropologii i Etnologii Kulturowej UW.

Murcott, Anne. 1988. "Sociological and social anthropological approaches to food and eating." World Review of Nutrition and Dietetics 55, I-40. http://doi.org/I0.1159/000415556.

Parreñas, Salazar Rhacell. 20or. Servants of Globalization: Migration and Domestic Work. Stanford, CA: Stanford University Press.

Parsons, M. Julie. 20I5. Gender, Class and Food: Families, Bodies and Health, Basingstoke, UK: Palgrave MacMillan. http://doi.org/IO.IO57/9781137476418.

Pasieka, Agnieszka. 20I5. "Opór, dominacja i teoria społeczna na przełomie XX i XXI wieku.” In Opór i dominacja. Antologia tekstów, edited by Agnieszka Pasieka and Katarzyna Zielińska, 7-30, Kraków: Zakład Wydawniczy Nomos.

Patzer, Helena. 20I5. Long-distance Care. The Practice of Sustaining Transnational Ties by Filipino Immigrants in Boston, PhD thesis, University of Warsaw.

Patzer, Helena. 20I8. "Unpacking the balikbayan box. Long-distance care through feeding and food consumption in the Philippines." Studia Socjologiczne 4 (23I), I3I-I48. http://doi.org/IO.24425/I22486.

Pine, Frances. 2000. "Kinship, gender and work in socialist and post-socialist rural Poland." In Gender, Agency and Change. Anthropological Perspective, edited by Victoria Ana Goddard, 86-Ioo, London: Routledge.

Pustułka, Paula, and Ślusarczyk, Magdalena 20I6. "Cultivation, compensation and indulgence: transnational short-term returns to Poland across three family generations." Transnational Social Review 6 (I-2), 78-92. http://doi.org/IO.I080/21931674.2016.II82312. 
Pustułka, Paula, and Struzik, Justyna, \& Ślusarczyk, Magdalena. 2015. "Caught between breadwinning and emotional provisions - the case of Polish migrant fathers in Norway." Studia Humanistyczne $A G H$ I4 (2), II7.

Pustułka, Paula, and Trąbka, Agnieszka (2018). "Private empowerment and public isolation: power in the stories of migrant 'Mother-Poles'." Identities 25 (6), 668-686. http://doi.org/Io.1080/10702 89X.2017.I291190.

Risman, J. Barbara. 2004. "Gender as a social structure: theory wrestling with activism." Gender and Society I8 (4), 429-540. http://doi.org/I0.II77/0891243204265349.

Scott, C. James 1985. Weapons of the Weak: Everyday Forms of Peasant Resistance. New Haven and London: Yale University Press.

Scott, B. Marvin, and Lyman, M. Stanford. 1968. "Accounts." American Sociological Review 33 (I), 46-62. http://doi.org/I0.2307/2092239.

Urbańska, Sylwia. 2015. Matka Polka na odlegtość. Z doświadczeń migracyjnych robotnic 1989-2010. Toruń: Wydawnictwo Naukowe Uniwersytetu Mikołaja Kopernika.

Urbańska, Sylwia. 2016. "Transnational Motherhood and Forced Migration. Causes and Consequences of the Migration of Polish Working-Class Women 1989-20I0." Central and Eastern European Migration Review 5 (I), 9-I28. http://doi.org/I0.I7467/ceemr.20I6.II.

Urbańska, Sylwia. 2018. "Assessing the significance of religion in gender and migration studies. New Aaenues for scholarly inquiry." Central and Eastern European Migration Review 7 (2), III-I24. http://doi.org/I0.17467/ceemr.2018.16

\section{AUTHOR'S CONTACT:}

Sylwia Urbańska

Faculty of Sociology, University of Warsaw

E-mail: urbanskas@is.uw.edu.pl

ORCID: 0000-0002-5632-8043

$$
\text { (C) }(1) \Theta
$$

